\title{
Plant polyphenols inhibit VacA, a toxin secreted by the gastric pathogen Helicobacter pylori
}

\author{
Francesco Tombola ${ }^{\mathrm{a}}$, Silvia Campello ${ }^{\mathrm{a}}$, Laura De Luca ${ }^{\mathrm{a}}$, Paolo Ruggiero ${ }^{\mathrm{b}}$, \\ Giuseppe Del Giudice ${ }^{\mathrm{b}}$, Emanuele Papini ${ }^{\mathrm{a}}$, Mario Zoratti ${ }^{\mathrm{a}, *}$ \\ ${ }^{a}$ CNR Institute of Neurosciences, Biomembranes section, and Department of Biomedical Sciences, University of Padova, Viale G. Colombo 3 , \\ 35121 Padua, Italy \\ ${ }^{\mathrm{b}}$ Immunobiology Research Institute Siena, CHIRON S.p.A., Via Fiorentina 1, 53100 Siena, Italy
}

Received 27 February 2003; accepted 11 April 2003

First published online 2 May 2003

Edited by Maurice Montal

\begin{abstract}
VacA is a major virulence factor of the widespread stomach-dwelling bacterium Helicobacter pylori. It causes cell vacuolation and tissue damage by forming anion-selective, ureapermeable channels in plasma and endosomal membranes. We report that several flavone derivatives and other polyphenols present in vegetables and plants inhibit ion and urea conduction and cell vacuolation by VacA. Red wine and green tea, which contain many of the compounds in question, also potently inhibit the toxin. These observations suggest that polyphenols or polyphenol derivatives may be useful in the prevention or cure of $H$. pylori-associated gastric diseases.

(C) 2003 Published by Elsevier Science B.V. on behalf of the Federation of European Biochemical Societies.
\end{abstract}

Key words: VacA; Gastritis; Polyphenol; Flavone; Green tea; Helicobacter pylori

\section{Introduction}

Infection by the stomach-dwelling bacterium Helicobacter pylori $[1,2]$ constitutes a major risk factor for gastritis, peptic ulcer, gastric cancer and mucosa-associated lymphoid tissue lymphoma. Some epidemiological studies have indicated a correlation between $H$. pylori seropositivity and environmental factors, including the diet: a lower incidence of infection has been associated with the consumption of vegetables (e.g. [3]), wine [4] and green tea [5].

The secreted vacuolating cytotoxin VacA $[2,6,7]$ can directly induce gastric epithelial damage in mice upon intragastric or oral administration [8,9], and it is believed to play an important role in the aetiology of ulcers. While vac $A^{-} H$. pylori strains grow well under laboratory conditions, and are able to infect animals, VacA confers a strong advantage during colonisation of the stomach in a mouse model and in competition against isogenic, vac $A^{-}$strains [10].

VacA forms oligomeric, anion-selective, urea-permeable channels in artificial and plasma membranes [11-14]. Urea conduction may well be the most relevant function of the toxin for $H$. pylori, which depends on urea supplied by the epithelium and hydrolysed by the bacterium's urease to buffer the $\mathrm{pH}$ in and around the cell. VacA owes its name to its

*Corresponding author. Fax: (39)-049-8276049.

E-mail address: zoratti@civ.bio.unipd.it (M. Zoratti). ability to cause vacuolation of cultured cells $[15,16]$ if activated by exposure to acid or basic $\mathrm{pH}$. The vacuoles, whose formation is strongly assisted by the presence of permeant amines, originate from late endosomal-lysosomal compartments [17]. We have proposed that VacA causes vacuolation because upon endocytosis it increases the permeability to anions of the membrane of late endosomes. This in turn causes depolarisation, increased $\mathrm{H}^{+}$pumping into the lumen by $\mathrm{V}$-ATPase, accumulation of $\mathrm{NH}_{4} \mathrm{Cl}$ and osmotically driven water influx and swelling [18], possibly accompanied by membrane fusion events. Our previous studies have identified a set of inhibitors of VacA activities, the most powerful of which are 5-nitro-2-(3-phenylpropylamino) benzoic acid (NPPB) and phloretin $\left(K_{\mathrm{D}} 18\right.$ and $15 \mu \mathrm{M}$ respectively in planar bilayer experiments) $[14,19,20]$.

We noticed structural similarities between VacA inhibitors such as 4,4'-diisothiocyanatostilbene-2,2'-disulphonic acid, NPPB and phloretin and some plant phenolic compounds, i.e. the most numerous and widespread class of phytochemicals: flavones, isoflavones, flavo- and flavanols, anthocyanidins, tannins and stilbene derivatives. They are present in variable amounts in many foods of vegetal origin, including wine and green tea. Several show anti-oxidant, anti-tumorigenic, anti-inflammatory and other medically relevant activities, and induce death and/or proliferation arrest in immortalised, tumour-derived cell lines (e.g. [21-24]). Because of these similarities, and of the reports of a relevance of the diet for $H$. pylori infection and gastric disease, we investigated whether red wine and green tea, both rich in flavonoids, catechins and tannins, as well as several representative polyphenols, acted as inhibitors of VacA.

\section{Materials and methods}

\subsection{Toxin}

The VacA isoform used was the s1/m1-type produced by strain CCUG 17874, isolated as previously described [25].

\subsection{Inhibitors}

Fig. 1 presents the polyphenols used in this study. They were purchased from Sigma (Milan, Italy) unless otherwise indicated. Stock solutions were prepared in dimethyl sulphoxide except for tannic acid (in ethanol).

Wines (vintage 2000) were produced on a local family vineyard by the traditional spontaneous fermentation process. No additives were used. The green tea solution was obtained by boiling $2 \mathrm{~g}$ of lyophilised and otherwise untreated leaves in 11 of distilled water for $5 \mathrm{~min}$. The extract was concentrated by evaporation under vacuum at $30^{\circ} \mathrm{C}$. 
Ethanol-free red and white wine concentrates were obtained in the same way. The volume fractions mentioned below and in the figures (e.g. 1:10) refer to (equivalent) concentrations of the original liquid, calculated on the basis of the concentration factor of the concentrate used.

\subsection{Cell culture}

HeLa cells were grown at $37^{\circ} \mathrm{C}$ in plastic flasks in Dulbecco's modified Eagle's medium plus foetal calf serum $(10 \%, \mathrm{v} / \mathrm{v})$, penicillin $(100$ $\mathrm{U} / \mathrm{ml})$ and streptomycin $(100 \mu \mathrm{g} / \mathrm{ml})$ in a $5 \% \mathrm{CO}_{2}$ atmosphere.

\subsection{Electrophysiology}

Planar bilayer experiments were conducted essentially as previously described [11]. Diphytanoylphosphatidylcholine (synthetic; Avanti Polar Lipids, Alabaster, AL, USA; purity $>99 \%$ ) was the membrane lipid. The standard medium was symmetrical $500 \mathrm{mM} \mathrm{KCl}, 0.5 \mathrm{mM}$ $\mathrm{CaCl}_{2}, 0.5 \mathrm{mM} \mathrm{MgCl}, 10 \mathrm{mM}$ HEPES/K$/ \mathrm{K}^{+}, \mathrm{pH}$ 7.2. For experiments involving acidification, $10 \mathrm{mM}$ citrate was also present. The toxin and inhibitors were added into the compartment (cis) containing the active electrode, whose voltage is reported with reference to the grounded<smiles></smiles><smiles></smiles>

4<smiles>Oc1ccc(-c2coc3cc(O)ccc23)c(O)c1</smiles>

7<smiles>O=C(Oc1cc(O)c(O)c(O)c1)c1ccc(O)c(OC(=O)c2ccc(O)c(O)c2)c1</smiles>

10<smiles>Oc1cc(O)cc(C=Cc2ccc(O)c(O)c2)c1</smiles>

13<smiles>O=C(Cc1ccc(O)cc1)c1ccc(O)cc1O</smiles>

16

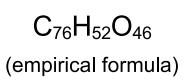

19

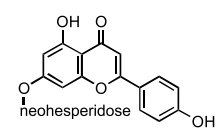

22

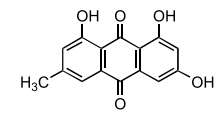

25<smiles>OC1=C(c2ccccc2)Oc2cc(O)c(O)c3c(O)c(O)c(O)c1c23</smiles>

2<smiles>O=C1OC2(O)c3cc(O)cc(O)c3OC1C(=O)C2O</smiles>

5<smiles>Oc1ccc(C2Oc3cc(O)cc(O)c3CC2O)c(O)c1</smiles><smiles>Oc1cc(O)c([C@@H]2Cc3c(O)cc(O)c(O)c3O2)cc1O</smiles>

11<smiles>Oc1ccc(C=Cc2cc(O)cc(O)c2)cc1</smiles>

14<smiles>CCCOC(=O)c1cc(O)c(O)c(O)c1</smiles>

17<smiles>O=C(Cc1ccc(O)cc1)c1c(O)cc(O)cc1O</smiles>

20<smiles>O=c1c2ccc(O)cc2oc2cc(O)cc(O)c12</smiles>

23<smiles></smiles>

26<smiles>Oc1c2cc(-c3ccccc3)cc1oc1c(O)cc(O)c(o2)c1O</smiles>

3<smiles>O=C1c2c(O)cc(O)cc2OC(c2ccc(O)c(O)c2)C1O</smiles><smiles>Oc1ccc([C@@H]2Oc3cc(O)cc(O)c3C[C@H]2O)c(O)c1</smiles>

9<smiles>O=C(O[C@H]1Cc2c(O)cc(O)cc2O[C@H]1c1cc(O)c(O)c(O)c1)c1cc(O)c(O)c(O)c1</smiles>

12<smiles>CC(Cc1ccc(O)c(O)c1)(Cc1ccc(O)c(O)c1)Cc1ccc(O)cc1C(c1ccc(O)cc1)(c1ccc(O)cc1)c1ccc(O)cc1</smiles>

18<smiles>COc1cc(O)cc(/C=C/c2ccc(OC)c(O)c2)c1</smiles>

21

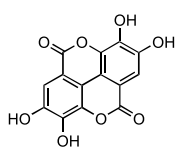

24<smiles>Oc1cc(O)cc(O)c1</smiles>

27 electrode in trans. A current (cations) flowing from cis to trans is defined as positive. To verify the reversibility of inhibition the cis compartment was perfused with fresh medium (a seven-fold larger volume). Titration data (each point the average of three to five independent determinations) were fitted using the relationship $\% \%_{\text {r.c. }}=$ $100-\mathrm{P}_{1} /\left(1+K_{\mathrm{D}} /[\mathrm{L}]\right)[19]$, a form of the Langmuir isotherm, in which $\%$ r.c. stands for the per cent residual current, [L] is the concentration of inhibitor, and $\mathrm{P}_{1}$ is a fitting parameter, whose physical meaning is the maximal percentage of inhibition theoretically observable at an infinite concentration of inhibitor. The toxin was added after preactivation at $37^{\circ} \mathrm{C}, \mathrm{pH} 2.0$ for $5-8 \mathrm{~min}$. Inhibitors were added after the current level had reached a plateau. Whole-cell patch-clamp experiments were conducted on HeLa cells, exposed or not to pre-activated VacA, essentially as described in [13]. The inhibitor was added using a pipette, and the chamber contents were thoroughly mixed by withdrawing and re-adding a fraction of the medium several times.

\subsection{Vacuolation}

Vacuolation assays were performed as described in [13]. The effects of the toxin and of the various inhibitors were documented by photographs and using the Neutral red uptake method [16].

\subsection{Urea permeation}

Assays were conducted using cultured HeLa cells, following the transmembrane flux of $\left[{ }^{14} \mathrm{C}\right]$ urea $(45 \mu \mathrm{M} ; 57 \mathrm{mCi} / \mathrm{mmol}$; Amersham Pharmacia Biotech, UK) essentially as described in [14]. The kinetics of urea efflux from pre-loaded cells were determined over a 30-min period after washing with phosphate-buffered saline containing the desired substances by liquid scintillation counting of samples taken at predetermined intervals. The inhibitory effects are expressed as the per cent inhibition of the increase of urea efflux induced by the toxin alone with respect to that of cells treated with no toxin.

\section{Results}

Red wine and green tea concentrates dramatically reduced current conduction by VacA in planar bilayer experiments (Fig. 2A,C,D). The addition to both bilayer chambers of enough concentrate to make the medium equivalent to a

Fig. 1. Structures of the polyphenols used in this study. The compounds are arranged in the same order as in Table 1. 1: Apigenin (4',5,7-trihydroxyflavone) (Fluka, Milan, Italy). 2: Baicalein (5,6,7trihydroxyflavone) (Aldrich, Milan, Italy). 3: Chrysin (5,7-dihydroxyflavone) (Fluka). 4: Myricetin (3,3',4',5,5',7-hexahydroxyflavone) (Fluka). 5: Morin (2',3,4',5,7-pentahydroxyflavone) (Riedelde-Haen, Milan, Italy). 6: Quercetin $\left(3,3^{\prime}, 4^{\prime}, 5,7\right.$-pentahydroxyflavone). 7: Genistein (4',5,7-trihydroxyisoflavone). 8: Catechin (3,3', 4',5,7-flavanpentol). 9: Epicatechin ([2R,3R]-2-[3,4-dihydroxyphenyl]3,4-dihydro-1[2H]-benzopyran-3,5,7-triol). 10: Epicatechin gallate ([2R,3R]-2-[3,4-dihydroxyphenyl]-3,4-dihydro-1[2H]-benzopyran-3,5,7triol 3-[3,4,5-trihydroxybenzoate]). 11: Epigallocatechin ([2R,3R]2-[3,4,5-trihydroxyphenyl]-3,4-dihydro-1[2H]-benzopyran-3,5,7-triol). 12: Epigallocatechin gallate ([2R,3R]-2-[3,4,5-trihydroxyphenyl]-3,4dihydro-1[2H]-benzopyran-3,5,7-triol 3-[3,4,5-trihydroxybenzoate]). 13: Piceatannol (3,3',4,5'-tetrahydroxy-trans-stilbene). 14: Resveratrol (3,4',5-trihydroxy-trans-stilbene). 15: Nordihydroguaiaretic acid (1,4-bis[3,4-dihydroxyphenyl]-2,3-dimethylbutane). 16: Phloretin (3[4-hydroxyphenyl]-1-[2,4,6-trihydroxyphenyl]-1-propanone). 17: $n$ Propylgallate (n-propyl-3,4,5-trihydroxybenzoate). 18: $p$-Rosolic acid (4-[bis(4-hydroxyphenyl)methylene]-2,5-cyclohexadienone (Riedel-deHaen). 19: Tannic acid (Riedel-de-Haen) (a mixture of compounds, mainly polygalloylglucoses; an average $\mathrm{MW}$ of 1700 was assumed for calculations). 20: Phloridzin (phloretin $2^{\prime}-O$ - $\beta$-D-glucoside). 21 : Rhapontin ( $4^{\prime}$-methoxy-3,3',5-stilbenetriol 3-O-glucoside). 22: Rhoifolin (apigenin 7-O-neoesperidoside). 23: Rutin $\left(3,3^{\prime}, 4^{\prime}, 5,7\right.$-pentahydroxyflavone 3- $O$-rutinoside). 24: Ellagic acid (4,4',5, $5^{\prime}, 6,6^{\prime}$-hexahydrodiphenic acid 2,6,2',6'-dilactone) (Fluka). 25: Emodin (1,3,8trihydroxy-6-methyl-9,10-anthracenedione) (Fluka). 26: Esculetin (6,7-dihydroxycoumarin) (Fluka). 27: Phloroglucinol (1,3,5-trihydroxybenzene) (Fluka). 

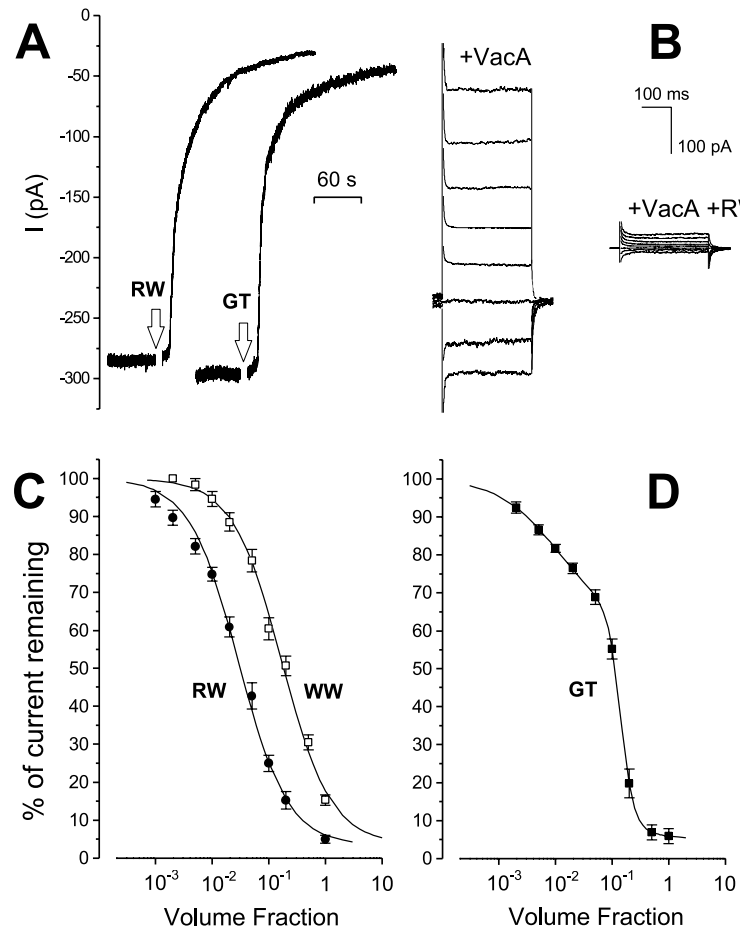

Fig. 2. Inhibition of VacA-mediated current conduction by wine and green tea concentrates. A,C,D: Bilayer experiments. V: -40 $\mathrm{mV}$. A: Sample current traces. Red wine (RW) or green tea (GT) concentrate was added to the cis chamber of the apparatus to give concentrations equivalent to $1 / 10(\mathrm{RW})$ or $1 / 5(\mathrm{GT})$ of the original solutions. B: A representative patch-clamp experiment on a $\mathrm{HeLa}$ cell: current traces before and after addition of RW concentrate to give an equivalent concentration of $1 / 10$. The voltage was varied in 20-mV steps from -60 to $+80 \mathrm{mV}$. C,D: Titration curves derived from experiments analogous to those illustrated in A. $\bullet$ : red wine; $\bigcirc$ : white wine; $\mathbf{\square}$ : green tea. The abscissa gives the equivalent concentration of wine or tea, taking as 1 that of the original (unconcentrated) beverage.

$10 \%$ solution of red wine or tea was sufficient to reduce the current by $75 \pm 2 \%$ and $45 \pm 3 \%$ respectively. White wine was less effective by a factor of about 6 , in line with a similarly lower average content of polyphenolic compounds [26]. Analogous results were obtained, as expected [13], in patch-clamp experiments on VacA-intoxicated HeLa cells (Fig. 2B). Since wine and tea are complex mixtures, inhibition may show complex features, as in the titration curve with green tea (Fig. 2D).

Lowering the $\mathrm{pH}$ of the experimental medium in both chambers of the bilayer apparatus, either before or after the addition of wine or tea concentrate, did not detectably influence the extent of inhibition at least in the range 7-4 (not shown). Bilayer experiments with a series of plant polyphenols and structurally related molecules upheld the hypothesis that the inhibitory effects of wine and tea are to be attributed to their content of compounds of this type (e.g. [26]). For each of the compounds listed in Table 1, titration curves similar to the ones in Fig. 3A were determined, and inhibition parameters (Table 1) were obtained by fitting the curves as described in Section 2.

In some cases the solubility of the polyphenol was the factor limiting the extent of inhibition as reflected in the corresponding entries in Table 1. We tested a few soluble glycosylated derivatives, all of which however proved less effective than the parent aglycones. To verify whether the inhibitory effects may be linked to the anti-oxidant properties of some of the compounds, we tested ascorbate, $\beta$-mercaptoethanol, diamide, dithiothreitol, $p$-chloromercuribenzenesulphonate and $\mathrm{CdCl}_{2}$. All these redox or $\mathrm{SH}$ group reagents were completely ineffective (not shown). Inhibition by tea, wine and tannic acid showed a biphasic time course, with a rapid initial phase followed by a slower inhibitory process, which could not be reversed by washing. The kinetics of inhibition by $5 \mu \mathrm{M}$ tannic acid are shown in Fig. 3B. The titrations by these agents (Fig. 2C,D) reflect essentially the rapid phase.

As expected [20], inhibition of current conduction was paralleled by inhibition of the passive urea transport mediated by the toxin in a cultured cell model (Fig. 4). Polyphenols did not inhibit $H$. pylori urease activity (not shown).

According to the current mechanistic model, inhibition of VacA channels ought to be paralleled by inhibition of vacuolation, provided the inhibitor can diffuse into the cell, so as to act at the endosome level. While many of the compounds tested caused a clearly observable inhibition of vacuolation (not shown), quantitative determinations were made difficult by accompanying cell sufferance and death. These effects are to be ascribed to the well-documented cytotoxicity of many polyphenols for cells of tumoural origin. In the cases of morin, catechin and tannic acid no effect - either on vacuolation or on cell survival - was detected. The reasons for this lack of activity remain to be determined. Among possible causes may be binding by serum components and/or the inability to permeate the cell membrane.

\section{Discussion}

A large literature describes an ever-increasing number of activities by wine, tea and individual plant phenolics on cellular processes, enzymes and channels. In many cases these interactions have potential clinical significance. The results reported here show that members of this family have an inhibitory effect on VacA, a toxin known to play a role in $H$. pylori colonisation and survival [10], and to cause epithelial damage [8,9]. All compounds that inhibited $\mathrm{Cl}^{-}$conduction also impaired plasma membrane urea permeation induced by VacA (Fig. 4). The two effects showed a quantitative correlation (Fig. 4B) despite the profound differences in experimental design, confirming that the same type of mechanism/structure is responsible for the transmembrane transport of ions and urea. Under these circumstances VacA inhibition may explain a possible relevance of dietary habits for the incidence of infection by $H$. pylori and of diseases such as gastritis and ulcer. These pathologies are linked to the activity of the toxin itself in the stomach. Ingestion of polyphenols may therefore be expected to decrease the probability of their insurgence in $H$. pylori-infected individuals and might also decrease inflammation and erosion after onset of the disease.

A few of the molecules listed in Table 1 are more powerful VacA inhibitors than NPPB, and exert their action at concentrations within the pharmacologically relevant range. The mechanistic details of inhibition, which may vary from compound to compound, remain to be investigated, and may be complex. Some of the compounds may act after partitioning into the membrane, in a manner similar to that proposed for NPPB [20].

While the known properties of tannins and the kinetics of 
inhibition by tannic acid (Fig. 3B) may suggest that unspecific multiple interactions and reactions might (partly) account for the inhibitory effects of these complex molecules, a correlation of structure and function suggests otherwise for the other compounds investigated. The most effective among the latter include resveratrol (no. 14 in Fig. 1), morin (no. 4) and piceatannol (no. 13). They share a structural motif consisting of two benzene rings, in a trans configuration with respect to a connecting two-atom planar bridge, substituted with two hydroxyls on one ring and (at least) one on the other, in positions 5, 7 and $4^{\prime}$ of the flavone skeleton $\left(3,5\right.$ and $4^{\prime}$ of the stilbene skeleton). Gallate moieties seem not to confer an advantage. Thus, e.g. myricetin (no. 5) is less powerful than either morin (no. 4) or quercetin (no. 6). Some compounds with other ring structures, e.g. ellagic acid (no. 24), proved essentially ineffective, despite being aromatic compounds with multiple hydroxyls. The conclusion seems warranted that VacA inhibition by polyphenols is due to specific, well-defined molecule-molecule interactions. Redox effects are unlikely to play a role, because no correlation is apparent between the reducing power of the compounds tested and their effectiveness as VacA inhibitors, and because of the lack of effect of the redox compounds mentioned above (see Section 3).

Currently $H$. pylori-symptomatic patients are treated with a proton pump inhibitor and two antibiotics. The success rate is high, but novel approaches are needed because of side effects, re-infection and the emergence of resistant strains [27]. Polyphenols may provide such a novel approach. While, as mentioned, phenolics affect many cellular functions, they have always been a component of human diet, with no harmful side effects even at high dosages. Studies report, for example, the oral administration of up to $150 \mathrm{mg}(0.44 \mathrm{mmol}) /$ day of quercetin to humans [28] and of $20 \mathrm{mg}(0.09 \mathrm{mmol}) / \mathrm{kg} / \mathrm{day}$ of
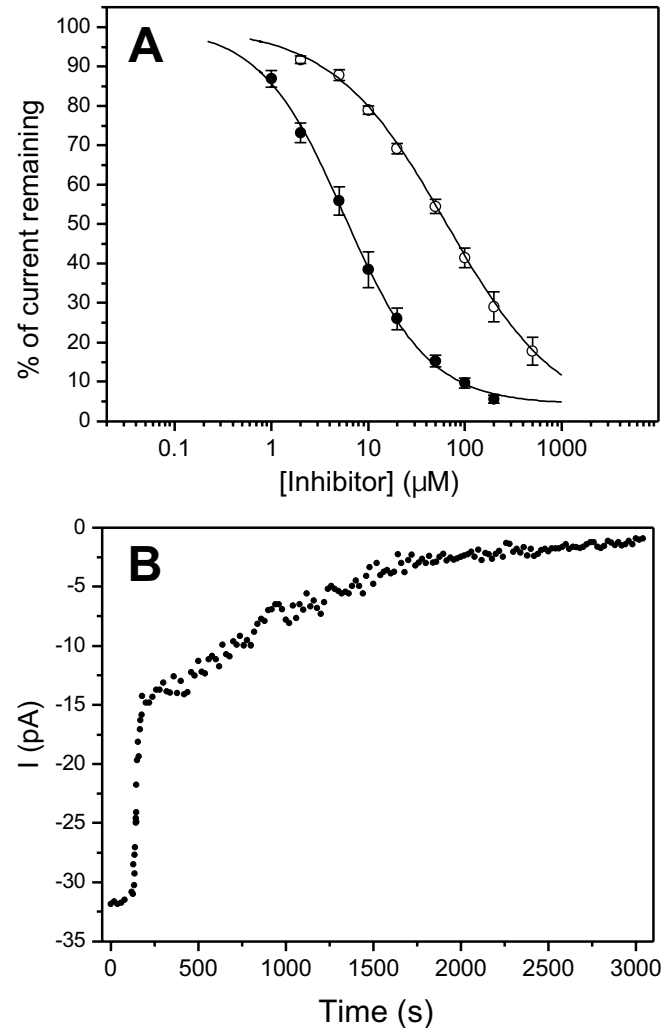

Fig. 3. The VacA channel is inhibited by several polyphenols. A: Two examples of titrations of current conduction by VacA in planar bilayer experiments. Conditions as in Fig. 2. ๑: Morin; $\bigcirc$ : Rhapontin. B: Kinetics of the inhibition of current conduction by $5 \mu \mathrm{M}$ tannic acid (see text for details).

Table 1

Inhibition of the VacA channel by different polyphenols

\begin{tabular}{|c|c|c|c|c|c|c|}
\hline Class & Compound & $K_{\mathrm{D}}(\mu \mathrm{M})$ & $\mathrm{P}_{1}$ & $\mathrm{IC}_{50}(\mu \mathrm{M})$ & {$[\mathrm{X}]_{\max }(\mu \mathrm{M})^{\mathrm{a}}$} & $\%{ }_{\text {inhib }}$ at $[\mathrm{X}]_{\max }$ \\
\hline \multirow[t]{6}{*}{ Flavones and flavonols } & Apigenin & $6 \pm 2$ & $39 \pm 3$ & - & 100 & $37 \pm 6$ \\
\hline & Baicalein & $57 \pm 14$ & $94 \pm 8$ & 65 & 200 & $77 \pm 6$ \\
\hline & Chrysin & $29 \pm 6$ & $73 \pm 7$ & 63 & 100 & $59 \pm 6$ \\
\hline & Morin & $5.7 \pm 0.3$ & $96 \pm 1$ & 6.2 & 200 & $94 \pm 2$ \\
\hline & Myricetin & $18 \pm 3$ & $68 \pm 4$ & 50 & 200 & $67 \pm 3$ \\
\hline & Quercetin & $13 \pm 2$ & $85 \pm 3$ & 19 & 200 & $85 \pm 4$ \\
\hline Isoflavones & Genistein & $31 \pm 5$ & $101 \pm 6$ & 30 & 200 & $87 \pm 6$ \\
\hline \multirow[t]{5}{*}{ Flavanols and derivatives } & Catechin & $123 \pm 15$ & $81 \pm 4$ & 198 & 500 & $66 \pm 4$ \\
\hline & $\mathrm{EC}$ & - & - & - & 300 & $13 \pm 3$ \\
\hline & EC gallate & $56 \pm 3$ & $93 \pm 2$ & 65 & 500 & $84 \pm 3$ \\
\hline & EGC & $367 \pm 88$ & $45 \pm 6$ & - & 500 & $26 \pm 3$ \\
\hline & EGC gallate & $53 \pm 11$ & $66 \pm 3$ & 166 & 500 & $61 \pm 5$ \\
\hline \multirow[t]{2}{*}{ Stilbene derivatives } & Piceatannol & $9.1 \pm 0.4$ & $96 \pm 1$ & 9.9 & 100 & $89 \pm 2$ \\
\hline & Resveratrol & $5.5 \pm 0.7$ & $97 \pm 3$ & 5.9 & 100 & $93 \pm 1$ \\
\hline \multirow[t]{5}{*}{ Other effective polyphenols } & NDGA & $12 \pm 2$ & 100 & 12 & 100 & $95 \pm 1$ \\
\hline & Phloretin & $16 \pm 1$ & $97 \pm 2$ & 17 & 200 & $91 \pm 1$ \\
\hline & n-PG & $153 \pm 13$ & $93 \pm 4$ & 178 & 500 & $72 \pm 3$ \\
\hline & $p$-Rosolic acid & $20 \pm 1$ & 100 & 20 & 200 & $95 \pm 1$ \\
\hline & Tannic acid & $2.7 \pm 0.5$ & $100 \pm 1$ & 2.7 & 100 & $99 \pm 1$ \\
\hline \multirow[t]{4}{*}{ Glycosylated polyphenols } & Phloridzin & $186 \pm 27$ & $84 \pm 5$ & 273 & 500 & $62 \pm 2$ \\
\hline & Rhapontin & $38 \pm 5$ & $85 \pm 3$ & 54 & 500 & $82 \pm 4$ \\
\hline & Rhoifolin & $67 \pm 7$ & $29 \pm 1$ & - & 500 & $25 \pm 5$ \\
\hline & Rutin & $68 \pm 9$ & $82 \pm 3$ & 106 & 500 & $74 \pm 3$ \\
\hline \multirow[t]{4}{*}{ Ineffective polyphenols } & Ellagic acid & - & - & - & 200 & $6 \pm 1$ \\
\hline & Emodin & - & - & - & 200 & 0 \\
\hline & Esculetin & - & - & - & 200 & $2 \pm 1$ \\
\hline & Phloroglucinol & - & - & - & 500 & 0 \\
\hline
\end{tabular}

EC, epicatechin; EGC, epigallocatechin; NDGA, nordihydroguaiaretic acid; n-PG, $n$-propylgallate.

${ }^{a}$ Highest concentration tested. 

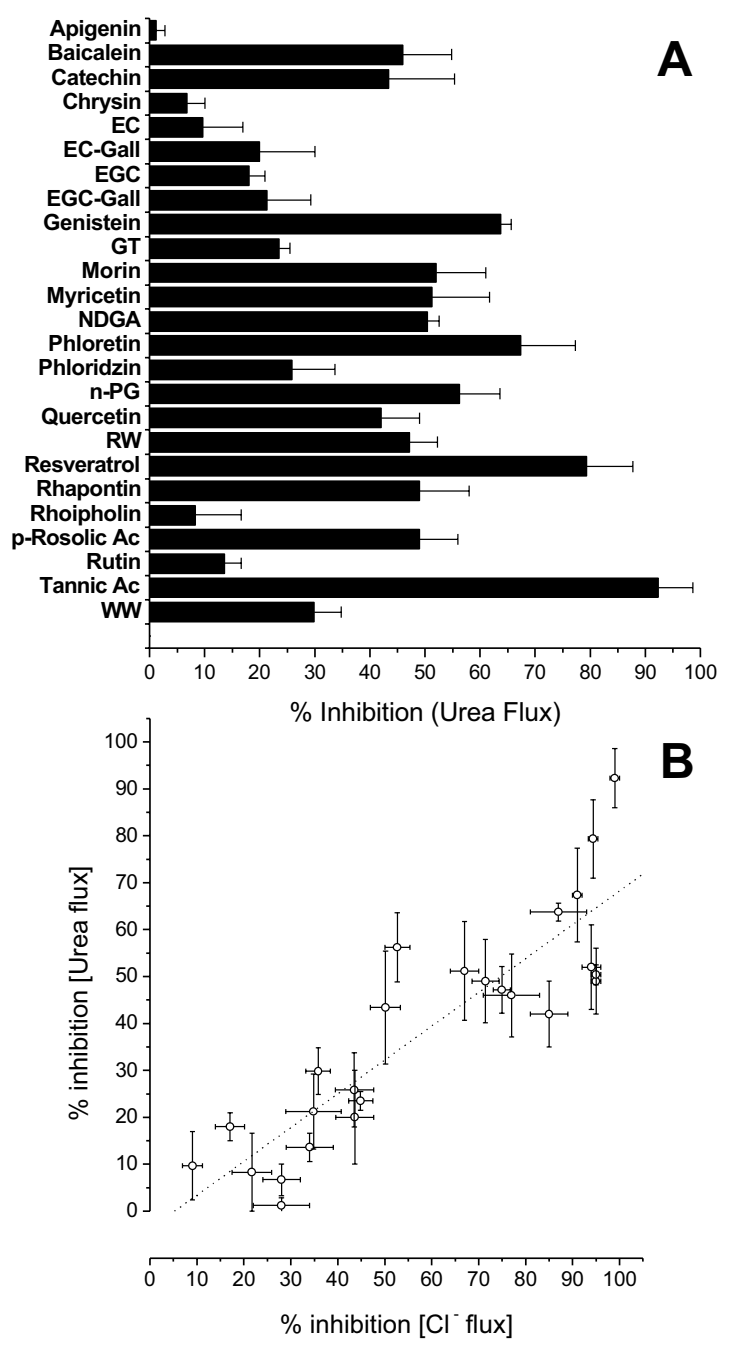

Fig. 4. Several polyphenols, wine and tea inhibit VacA-mediated transmembrane urea flux. A: Histogram showing the effect of the tested substances on the efflux of $\left[{ }^{14} \mathrm{C}\right]$ urea from cells exposed to VacA. Compounds were used at a concentration of $200 \mu \mathrm{M}$ except for apigenin and chrysin $(20 \mu \mathrm{M})$ and epicatechin gallate, epigallocatechin gallate and rutin $(50 \mu \mathrm{M})$. Wines (RW, WW) and tea (GT) were added at a final volume fraction of 0.1 . B: Plot relating per cent inhibition of urea flux to per cent inhibition of current conduction by the various compounds. Dotted line: linear regression fit $(r-0.88)$. Data are the mean of at least four experiments and bars represent \pm S.E.M.

resveratrol to rats [29]. Since VacA is produced in the stomach, complications associated with absorption of polyphenols would be no obstacle to their possible pharmaceutical application in this field. The toxin is inhibited by wine or tea equally well at $\mathrm{pH}$ values near 7 or 4 , the latter being lower than the near-neutral $\mathrm{pH}$ believed to prevail near the stomach mucosa, where H. pylori dwells [2]. Flavonoids and flavonoid glycosides are thought to be chemically stable under the conditions of the human stomach [30]. The persistence of inhibition by tannin in time (irreversibility) may also be important in vivo, prolonging the effect of a transient increase of its concentration (e.g. after a meal).

VacA plays a role in infection [10] by $H$. pylori and possibly in its survival in the stomach, but its inhibition would be expected to be of little consequence for bacteria growing in the laboratory in a nutrient-rich and neutral environment. Besides hindering infection by the bacterium, polyphenols may be expected to exert beneficial effects by limiting erosion of the gastric mucosa and the other biological effects mediated by the toxin. These aspects are currently under investigation.

In conclusion, we have shown that a group of natural, easily available, bioactive, reputedly beneficial compounds inhibit one of the major factors accounting for the virulence and pathogenicity of $H$. pylori. Their use as agents for therapy or prevention deserves consideration.

Acknowledgements: We thank C. Montecucco, I. Szabò, S. Garbisa and F. Ursini for useful discussions, L. Morbiato, L. Lauretti and L. Pancotto for technical help. This work was supported by CNR, Progetto Finalizzato Biotecnologie (97.01168.PF49), by a University of Padua 2001 Young Researcher grant to F.T. and by a PRIN 2000 grant to E.P.

\section{References}

[1] Montecucco, C. and Rappuoli, R. (2001) Nat. Rev. Mol. Cell Biol. 2, 457-466.

[2] Achtman, M. and Suerbaum, S. (Eds.) (2001) Helicobacter pylo$r i$ : Molecular and Cellular Biology, Horizon Scientific, Wymondham.

[3] Shinchi, K., Ishii, H., Imanishi, K. and Kono, S. (1997) Scand. J. Gastroenterol. 32, 651-655.

[4] Rosenstock, S.J., Jorgensen, T., Andersen, L.P. and Bonnevie, O. (2000) Scand. J. Publ. Health 28, 32-40.

[5] Suadicani, P., Hein, H.O. and Gyntelberg, F. (1999) Scand. J. Gastroenterol. 34, 12-17.

[6] Montecucco, C., Papini, E., de Bernard, M. and Zoratti, M. (1999) FEBS Lett. 452, 16-21.

[7] Papini, E., Zoratti, M. and Cover, T.L. (2001) Toxicon 39, $1757-$ 1767.

[8] Telford, J.L., Ghiara, P., Dell'Orco, M., Comanducci, M., Burroni, D., Bugnoli, M., Tecce, M.F., Censini, S., Covacci, A., Xiang, Z., Papini, E., Montecucco, C., Parente, L. and Rappuoli, R. (1994) J. Exp. Med. 179, 1653-1658.

[9] Ghiara, P., Marchetti, M., Blaser, M.J., Tummuru, M.K., Cover, T.L., Segal, E.D., Tompkins, L.S. and Rappuoli, R. (1995) Infect. Immun. 63, 4154-4160.

[10] Salama, N.R., Otto, G., Tompkins, L. and Falkow, S. (2001) Infect. Immun. 69, 730-736.

[11] Tombola, F., Carlesso, C., Szabò, I., de Bernard, M., Reyrat, J.M., Telford, J.L., Rappuoli, R., Montecucco, C., Papini, E. and Zoratti, M. (1999) Biophys. J. 76, 1401-1409.

[12] Iwamoto, H., Czajkowsky, D.M., Cover, T.L., Szabo, G. and Shao, Z. (1999) FEBS Lett. 450, 101-104.

[13] Szabò, I., Brutsche, S., Tombola, F., Moschioni, M., Satin, B. Telford, J.L., Rappuoli, R., Montecucco, C., Papini, E. and Zoratti, M. (1999) EMBO J. 18, 5517-5527.

[14] Tombola, F., Morbiato, L., Del Giudice, G., Rappuoli, R., Zoratti, M. and Papini, E. (2001) J. Clin. Invest. 108, 929-937.

[15] Leunk, R.D., Johnson, P.T., David, B.C., Kraft, W.G. and Morgan, D.R. (1988) J. Med. Microbiol. 26, 93-99.

[16] Cover, T.L. and Blaser, M.J. (1992) J. Biol. Chem. 267, 10570 10575

[17] Papini, E., de Bernard, M., Milia, E., Zerial, M., Rappuoli, R. and Montecucco, C. (1994) Proc. Natl. Acad. Sci. USA 91, 9720 9724.

[18] Morbiato, L., Tombola, F., Campello, S., Del Giudice, G., Rappuoli, R., Zoratti, M. and Papini, E. (2001) FEBS Lett. 508, 479483.

[19] Tombola, F., Oregna, F., Brusche, S., Szabò, I., Del Giudice, G., Rappuoli, R., Montecucco, C., Papini, E. and Zoratti, M. (1999) FEBS Lett. 460, 221-225.

[20] Tombola, F., Del Giudice, G., Papini, E. and Zoratti, M. (2000) Biophys. J. 79, 863-873.

[21] Kuntz, S., Wenzel, U. and Daniel, H. (1999) Eur. J. Nutr. 38, $133-142$.

[22] Fremont, L. (2000) Life Sci. 66, 663-673. 
[23] Wang, H.-K. (2000) Exp. Opin. Invest. Drugs 9, 2103-2119.

[24] Lu, Y.P., Lou, Y.R., Xie, J.G., Peng, Q.Y., Liao, I., Yang, C.S., Huang, M.T. and Conney, A.H. (2002) Proc. Natl. Acad. Sci. USA 99, 12455-12460.

[25] Manetti, R., Massari, P., Burroni, D., de Bernard, M., Marchini, A., Olivieri, R., Papini, E., Montecucco, C., Rappuoli, R. and Telford, J. (1995) Infect. Immun. 63, 4476-4480.

[26] German, J.B. and Walzer, R.L. (2000) Annu. Rev. Nutr. 20, 561568.
[27] Del Giudice, G., Covacci, A., Telford, J.L., Montecucco, C. and Rappuoli, R. (2001) Annu. Rev. Immunol. 19, 523-563.

[28] Erlund, I., Kosonen, T., Alfthan, G., Maenpaa, J., Perttunen, K., Kenraali, J., Parantainen, J. and Aro, A. (2000) Eur. J. Clin. Pharmacol. 56, 545-553.

[29] Juan, M.E., Vinardell, M.P. and Planas, J.M. (2002) J. Nutr. 132, 257-260.

[30] Gee, J.M., DuPont, M.S., Rhodes, M.J. and Johnson, I.T. (1998) Free Radic. Biol. Med. 25, 19-25. 